\title{
New Opportunities in Crystalline Silicon R\&D
}

Y.S. Tsuo, T.H. Wang, and T.F. Ciszek

National Renewable Energy Laboratory

P. Menna

ENEA, Portici, Italy

Presented at the National Center for Photovoltaics Program Review Meeting Denver, Colorado

September 8-11, 1998

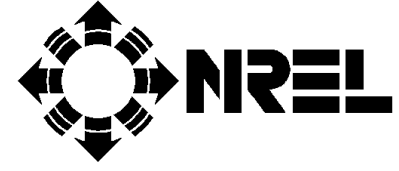

National Renewable Energy Laboratory 1617 Cole Boulevard Golden, Colorado 80401-3393

A national laboratory of the U.S. Department of Energy Managed by Midwest Research Institute for the U.S. Department of Energy under contract No. DE-AC36-83CH10093

Work performed under task number PV802401

October 1998 


\begin{abstract}
NOTICE
This report was prepared as an account of work sponsored by an agency of the United States government. Neither the United States government nor any agency thereof, nor any of their employees, makes any warranty, express or implied, or assumes any legal liability or responsibility for the accuracy, completeness, or usefulness of any information, apparatus, product, or process disclosed, or represents that its use would not infringe privately owned rights. Reference herein to any specific commercial product, process, or service by trade name, trademark, manufacturer, or otherwise does not necessarily constitute or imply its endorsement, recommendation, or favoring by the United States government or any agency thereof. The views and opinions of authors expressed herein do not necessarily state or reflect those of the United States government or any agency thereof.
\end{abstract}

Available to DOE and DOE contractors from:

Office of Scientific and Technical Information (OSTI)

P.O. Box 62

Oak Ridge, TN 37831

Prices available by calling 423-576-8401

Available to the public from:

National Technical Information Service (NTIS)

U.S. Department of Commerce

5285 Port Royal Road

Springfield, VA 22161

703-605-6000 or 800-553-6847

or

DOE Information Bridge

http://www.doe.gov/bridge/home.html 


\title{
New Opportunities in Crystalline Silicon R\&D
}

\author{
Y.S. Tsuo, P. Menna, * T.H. Wang, and T.F. Ciszek \\ National Renewable Energy Laboratory, Golden, CO 80401, USA \\ *ENEA, Energy Deparment 80055 Portici, Italy
}

\begin{abstract}
To support the expected growth of the silicon solar cell industry, we believe that research and development (R\&D) activities should be carried out in the following areas: polysilicon feedstock for the PV industry; thin-layer silicon deposition methods, and more environmentally benign cell and module manufacturing processes. For each of these activities, we identify the main issues that needed to be addressed.
\end{abstract}

\section{INTRODUCTION}

The worldwide PV module shipments will reach 150 MW/year by the end of 1998, doubling the 1994 shipments of $72 \mathrm{MW} /$ year. Crystalline-silicon solar cells currently account for $87 \%$ of the worldwide photovoltaic (PV) module shipment (Fig. 1). For crystal growth feedstock, the silicon PV industry has been relying on waste material from the semiconductor silicon industry and on secondary polysilicon, the excess or rejected material from electronic-grade polysilicon production. Secondary polysilicon, over 2,000 metric tons in 1997 , amounts to about $10 \%$ of the worldwide polysilicon production.

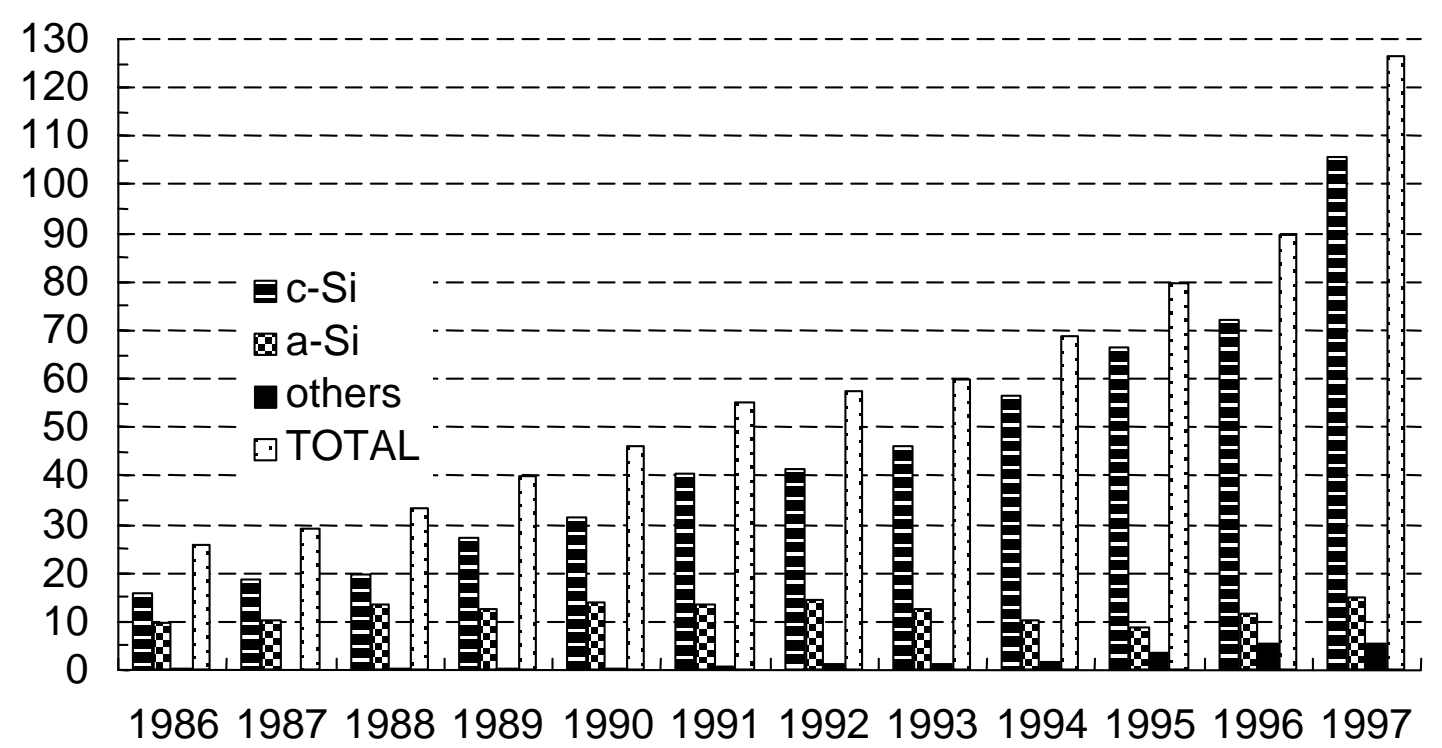

Figure 1. Worldwide PV shipments (in MW) by cell technology. 
If the PV industry continues to grow at the present rate, which in recent years has been higher than the growth rate of the integrated-circuit (IC) industry, and if crystalline silicon continues to be the dominant technology of the PV industry, then new sources of polysilicon for the PV industry are needed (Fig. 2). Furthermore, as the silicon PV industry continues to expand, the environmental impact of its manufacturing processes and products will receive increasing attention, because one of the primary benefits of renewable energy generation is its low environmental impact.

We have identified three research and development areas that we believe need to be extensively investigated in the near future to ensure the expected growth of the crystalline-silicon PV industry:

(1) Fresh approaches for solving the problem of polysilicon feedstock for the PV industry,

(2) New thin-layer silicon deposition methods, and

(3) More environmentally benign cell and module manufacturing processes.

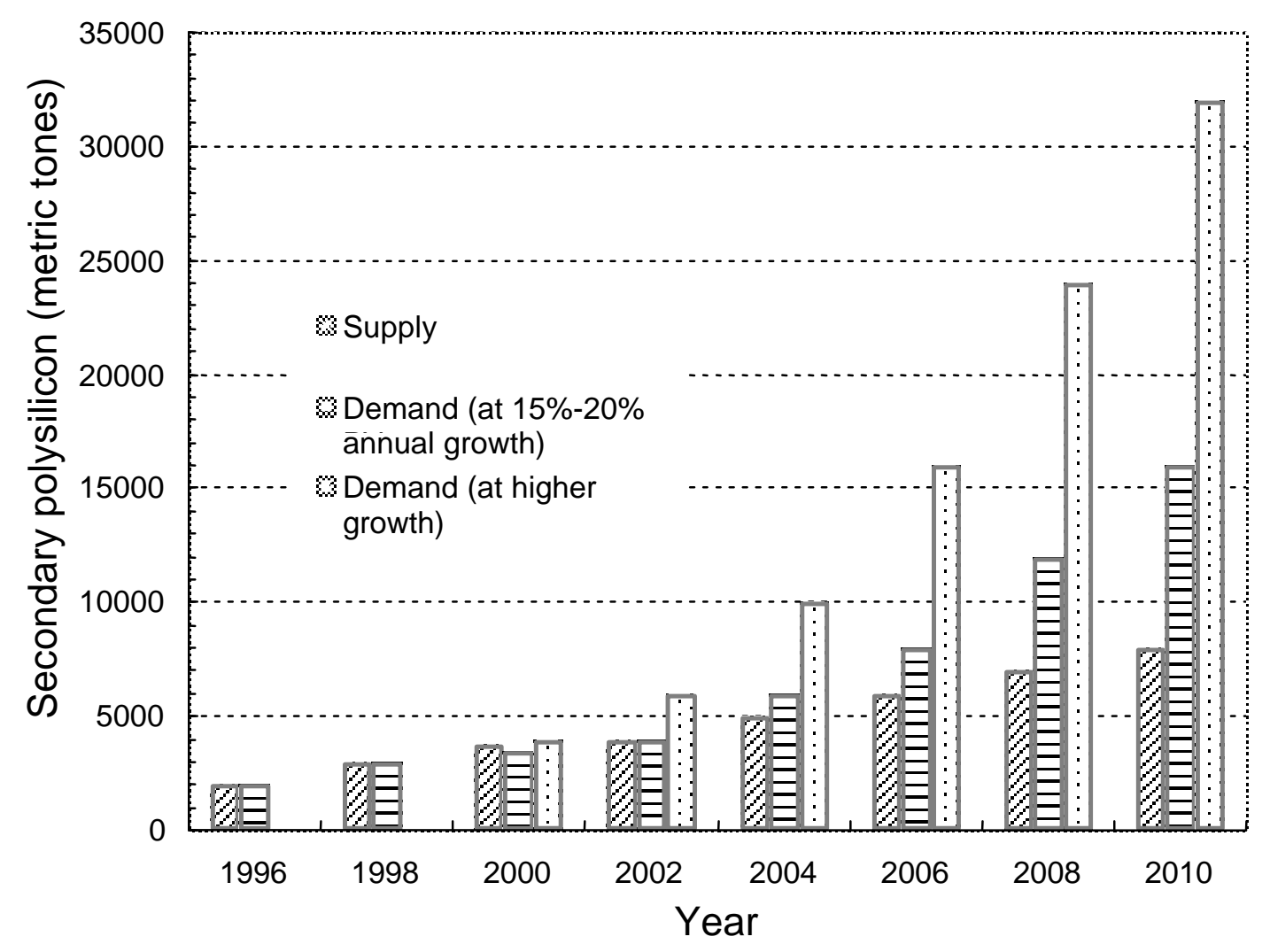

Figure 2. Forecasted supply and demand of secondary polysilicon. The projected supply of secondary polysilicon is based on the assumption that $10 \%-15 \%$ of total production is available at a cost lower than $\$ 20 / \mathrm{kg}$. The projected demand is based on a conversion of 20 metric tons of polysilicon per MW, assuming two different scenarios. (Reference 1) 


\section{NEW OPPORTUNITIES FOR THE POLYSILICON SUPPLY}

Polysilicon feedstock for the PV industry needs to cost less than $\$ 20 / \mathrm{kg}$, but can have relaxed impurity requirements compared with electronic-grade polysilicon. To produce polysilicon specifically for the PV industry, we need new approaches that use less energy and are more environmentally friendly than the conventional method based on trichlorosilane (2). Examples include a chlorine-free process $(2,3)$ that is being developed jointly by the National Renewable Energy Laboratory (NREL) and the Intersolarcenter (Moscow, Russia) and a purification method based on poroussilicon etching and annealing being developed jointly by NREL and the National Agency for New Technology Energy and Environment (ENEA, Naples, Italy).

\section{Low-Temperature, Chlorine-Free Processes for Polysilicon Production}

A promising chlorine-free method of producing solar-grade polysilicon uses metallurgical-grade silicon (MG-Si) and absolute alcohol as the starting materials (3). This new process requires only from 15 to $30 \mathrm{kWh}$ of energy per $\mathrm{kg}$ of polysilicon produced vs. about $300 \mathrm{kWh} / \mathrm{kg}$ for the trichlorosilane method. The silicon yield (polysilicon and the main by-product, silica sol) is in the $80 \%$ to $95 \%$ range vs. $6 \%$ to $20 \%$ for the trichlorosilane method. The cost goal is US\$10 per kg of solar-grade polysilicon. The basic processing stages of this chlorine-free polysilicon production process are the following:

I. Reaction of $\mathrm{MG}-\mathrm{Si}$ with alcohol at $280^{\circ} \mathrm{C}$ :

$$
\mathrm{Si}+3 \mathrm{C}_{2} \mathrm{H}_{5} \mathrm{OH} 280^{\circ} \mathrm{C} \text {, catalyst } \mathrm{Si}\left(\mathrm{OC}_{2} \mathrm{H}_{5}\right)_{3} \mathrm{H}+\mathrm{H}_{2}
$$

II. Disproportion of triethoxysilane:

$$
4 \mathrm{Si}\left(\mathrm{OC}_{2} \mathrm{H}_{5}\right)_{3} \mathrm{H} \text { catalyst } \mathrm{SiH}_{4}+3 \mathrm{Si}\left(\mathrm{OC}_{2} \mathrm{H}_{5}\right)_{4}
$$

III. Hydrolysis of tetraethoxysilane:

$$
\mathrm{Si}\left(\mathrm{OC}_{2} \mathrm{H}_{5}\right)_{4}+2 \mathrm{H}_{2} \mathrm{O} \text {----- } \mathrm{SiO}_{2}+4 \mathrm{C}_{2} \mathrm{H}_{5} \mathrm{OH}
$$

IV. Pyrolysis of silane:

$$
\mathrm{SiH}_{4} \quad 850^{\circ} \mathrm{C}-900^{\circ} \mathrm{C} \mathrm{Si}+2 \mathrm{H}_{2}
$$

For solar-grade polysilicon, the silane will undergo a simplified cycle of purification, and reaction (4) can be carried out in a fluidized-bed reactor. 


\section{Purification of MG-Si by Porous-Silicon Etching}

The cost of MG-Si is only about $\$ 1.5 / \mathrm{kg}$. A method of directly purifying MG-Si without melting can greatly reduce the cost of polysilicon. We have processed MG-Si substrates in a sequence of porous-silicon (PS) etching and annealing, at $1000^{\circ} \mathrm{C}$ for 30 minutes for purification. Secondary-ion mass spectroscopy depth profiles show the accumulation of heavy metals $(\mathrm{Al}, \mathrm{Cr}, \mathrm{Fe}$, and $\mathrm{Cu}$ ) and boron near the surface, particularly when concentrated light is used for the annealing. To explain these findings, we have invoked both the large surface area induced by the porous-silicon etch and an enhancement of the impurity diffusion by the intense light. Based on the above process sequence, followed by a removal of the heavily contaminated poroussilicon surface layers, a low-cost purification procedure of MG-Si substrates is conceivable (4).

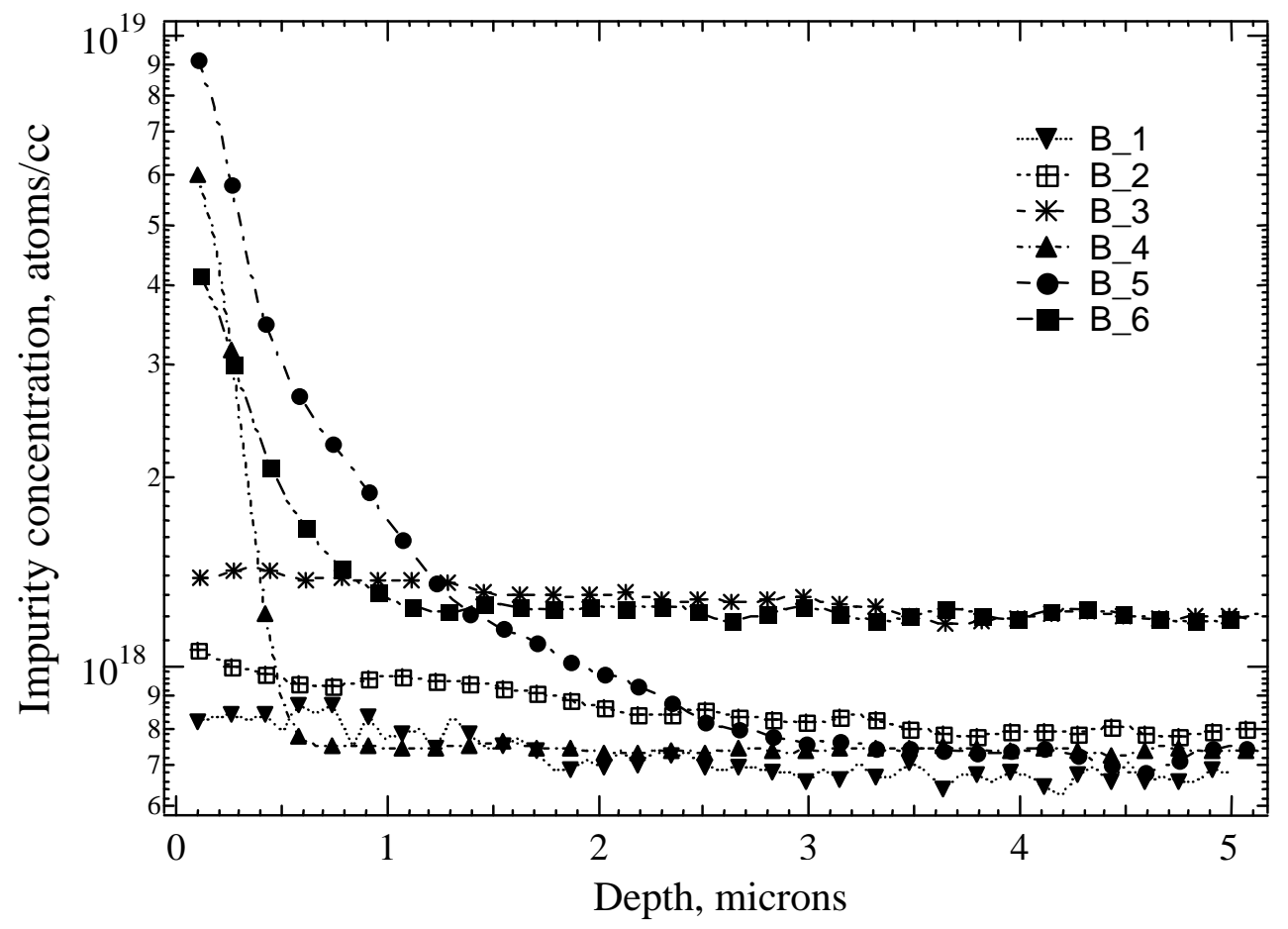

Figure 3. Boron concentration (in atoms $/ \mathrm{cm}^{3}$ ) measured against the distance from the surface (in $\mu \mathrm{m}$ ) for the whole set of processing conditions. An accumulation of boron within the first 1-2 micrometers is visible for the samples that have been etched and heat-treated (condition set \# 5 and 6) with respect to the starting sample (conditions set \# 1). For the PS-etched sample (\# 4), it is possible to see a boron accumulation closer to the surface. 


\section{THIN-LAYER SILICON ON LOW-COST SUBSTRATES}

Thin-layer crystalline-Si solar cells have great potential for low cost, high efficiency, low material consumption, long-term stability, and environmental friendliness. The challenge in developing this technology is in fabricating an active silicon layer of sufficient electronic quality, with a thickness of $10 \mu \mathrm{m}$ or more, at a deposition rate of about $1 \mu \mathrm{m} / \mathrm{min}$, and on a low-cost substrate such as glass. The principal requirement on electronic quality is a long minority-carrier diffusion length comparable to the layer thickness, which requires that the grains have similar size.

Different approaches have been attempted with only limited success. One of the promising methods is fast epitaxial growth of high-quality layers on cast metallurgical-grade $\mathrm{Si}$ substrates. The liquid-phase epitaxy technique based on $\mathrm{Cu}-\mathrm{Al}$ solutions (5) results in isotropic growth due to high silicon content in the solution and superior crystallinity because of its near-equilibrium growth nature. However, this second characteristic also places stringent requirements on the substrate of being silicon and free of foreign material inclusions.

A gas-phase growth technique would be needed to deposit large-grain polycrystalline thin-layer silicon on a foreign substrate at a high rate with minimum contamination. The technique needs to provide enough driving force for heterogeneous nucleation and reduced number of nucleation sites. Alternately, a seeding silicon layer on a foreign substrate may be used.

\section{ENVIRONMENTALLY BENIGN PROCESSES FOR MANUFACTURING SILICON SOLAR CELLS AND MODULES}

The manufacturing of silicon solar cells-from crystal growth, to ingot slicing, to wafer cleaning, to device processing, to encapsulation-requires many steps that are energy intensive and use large amounts of water and toxic chemicals. There are significant opportunities for the PV industry to implement more environmentally benign manufacturing approaches that often have the potential for significant cost reduction by reducing energy use and/or the purchase volume of new chemicals and by cutting the amount of used chemicals that must be discarded.

We have recently discussed new and more environmentally benign approaches for manufacturing silicon cells and modules (2) including:

- Water-soluble or water-based slurries for multiple-wire saws

- Reduction, recovery, recycle, reuse, and substitution for water and chemical usage for wafer cleaning and etching

- Reducing or eliminating the use of perfluorinated compounds for cell processing

- No-clean flux

- Lead-free solder. 


\section{CONCLUSIONS}

We have discussed three $R \& D$ areas that are important to support the expected growth of the silicon solar cell industry. The development of low-cost polysilicon production techniques and more environmentally benign cell and module processing methods will ensure the continued expansion of the present silicon PV industry. The development of viable thin-layer silicon solar cells on low-cost substrates will dramatically reduce the cost and environmental impact of the silicon PV industry.

\section{ACKNOWLEDGEMENTS}

We thank Prof. D.S. Strebkov and Dr. A. Pinov of the Intersolarcenter for helpful discussions. This work is supported by the U.S. Department of Energy under Contract Number DE-AC36-83CH10093.

\section{REFERENCES}

1 Maurits, J., "Polycrystalline Silicon -World Demand and Supply," presented at the 8th Workshop on Crystalline Silicon Solar Cell Materials and Processes, August 17-19, 1998, Copper Mountain, Colorado, USA.

2 Tsuo, Y.S.; Gee, J. M.; Menna, P.; Strepkov, D. S.; Pinov, A.; and Zadde, V., "Environmentally Benign Silicon Solar Cell Manufacturing", presented at the $2^{\text {nd }}$ World Conference and Exhibition on Photovoltaic Solar Energy Conversion, 6-10 July 1988, Vienna, Austria.

3 Strepkov, D. S.; Pinov, A.; Zadde, V.; Tsuo, Y. S.; Tourian, K.; Murphy, L.; and Gee, J. M., "Polysilicon Production in the Commonwealth of Indipendent States", presented at the 8th Workshop on Crystalline Silicon Solar Cell Materials and Processes, August 17-19, 1998 Copper Mountain, Colorado, USA.

4 Menna, P.; Tsuo, Y.S.; Al-Jassim, M.M.; Asher; S.E.; Matson R.; and Ciszek, T.F., "Purification of metallurgical-Grade Silicon by Porous-Silicon Etching," Presented at the $2^{\text {nd }}$ World Conference and Exhibition on Photovoltaic Solar Energy Conversion, 6-10 July 1998, Vienna, Austria.

5 Wang, T.H.; Ciszek, T.F.; Schwerdtfeger, C.R.; Moutinho, H.; and Matson, R., "Growth of Silicon Thin Layers on Cast MG-Si from Metal Solutions for Solar Cells," Solar Energy Materials and Solar Cells 41/42 (1996) 19-30. 